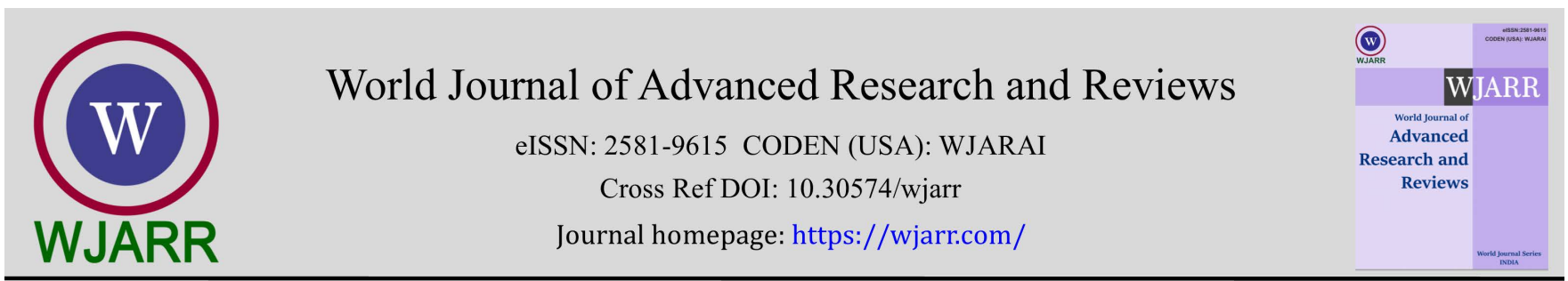

(RESEARCH ARTiClE)

\title{
Nutritional diversity of underutilized plant species collected from Aegean Region of Turkey
}

\author{
Tansel Kaygısız Aşçıŏul 1, Bülent Yağmur ${ }^{2}$, Mehmet Kadri Bozokalfa 1, ${ }^{*}$ and Dursun Eşiyok 1 \\ ${ }^{1}$ Department of Horticulture, Faculty of Agriculture, Ege University, Bornova 35100 Izmir, Turkey. \\ ${ }^{2}$ Department of Soil Science and Plant Nutrition, Faculty of Agriculture, Ege University, Bornova 35100 Izmir, Turkey.
}

World Journal of Advanced Research and Reviews, 2021, 12(02), 603-615

Publication history: Received on 16 October 2021; revised on 25 November 2021; accepted on 27 November 2021

Article DOI: https://doi.org/10.30574/wjarr.2021.12.2.0620

\begin{abstract}
The objective of the present work was to evaluate variability for dry matter, protein and mineral $\mathrm{N}$ (nitrogen), $\mathrm{P}$ (phosphorus), K (potassium), Ca (calcium), Mg (magnesium) composition of nutritionally important and widely consumed wild edible plants in Aegean region of Turkey, and to assess their mineral diversity using multivariate analysis. The plant material comprises 17 edible plants collected from native found, the data were subject to analysis of variance, and a Pearson correlation test used to determine the correlations between dry matter, protein content and $\mathrm{N}$, $\mathrm{P}, \mathrm{K}, \mathrm{Ca}, \mathrm{Mg}$ composition. Principal component analysis was performed on the result of examine compositions and the factor loadings, eigenvalues and percentage of cumulative variance were calculated, the patterns of relationships among nutritive element were shown three-dimension scatter plot. Multivariate analysis revealed considerable variation for the most of concentration and explained $81.49 \%$ of total variation accounted for three PC axes. The data reveal that selected wild plant provide significant nutrition and exhibited great variability among the species. Although soil mineral concentration, availability, fertilization and environment may have influenced on nutrient accumulation in plant tissue, genetic variability is considerable influenced on mineral composition of plant.
\end{abstract}

Keywords: Minerals; Multivariate analysis; Nutritional value; Wild edible plants

\section{Introduction}

Wild edible plants have been used as a spice, vegetable or foodstuff, and several ethnobotanical studies underlined that wild vegetables constitute of wild food plants widely harvested and consume in the Mediterranean countries [1, 2, 3]. In many countries rural people traditionally consume wide range of leafy vegetables and several studies argue that wild edible plant conserve important nutrient and non-nutrient elements comparing to the cultivated species [4,5], such as contain more vitamin $\mathrm{C}$ and pro-vitamin A. Furthermore, many neglected and underutilized species require less care are not affected by pesticide, well adapted to low input agriculture compared to the cultivated vegetables [6, 7]. In addition, edible plants are least expensive sources for number of nutrients and provide minerals, vitamins and essential fatty acids, and also observe flavor, odor which enhance taste and color in diets $[8,9,10]$. In addition, wild edible species are one of the important primary sources income for poor communities [11], some of them have been known as a functional food and contain physiologically active ingredients [12].

Wild edible species now considered as weeds found in agricultural fields, orchards, pastures, fallow lands vacant lots and roadsides [4]. They play an important role in food production, and consumption of wild edible species is increasing in many parts of the globe, however, widespread knowledge of edible wild plants does not provide much information on their nutritional significance and we need to focus on more research work on nutritional composition of wild edible plants due to their better nutritional value $[5,11,13,14,15,16]$. Consumption of underutilized crops or wild edible

\footnotetext{
* Corresponding author: Mehmet Kadri Bozokalfa

Department of Horticulture, Faculty of Agriculture, Ege University, Bornova 35100 İzmir, Turkey.
} 
plants effective way to reduce micronutrient deficiencies, and observe healthy diet particularly in poor people in developing countries. Dogan et al. [17] argue that wild plants have pivotal role by complementing staple foods for balanced diet by supplying trace elements, vitamins and minerals $[18,19,20]$.

Turkey natural habitat and diverse ecological condition accompanied by wide range of plant diversity resulted numerous plant species can be traditionally used as food sources in Turkish cuisine [21, 22, 23, 24]. Ethnobotanical surveys reported that climatic differences, together with a high topographic and geological diversity present the richest flora across the Turkey. Number of examples from different region of the country indicate that diversity of edible species and consumption at an aggregated level. Consumption of these plants related with cultural diversity, and also number of species consumed as vegetables depend on knowledge of people who living in province. There are important regional differences in traditional wild edible plant consumption and green wild vegetables are frequently sold in local markets. Abak and Duzenli [25] pointed out nearly 40 wild plants consumed as a vegetable in Turkey. Tan et al. [26] surveyed Mediterranean region of Turkey and reported empirical evidence about wild edible plants and showed over ninety species consumed as vegetables. Dogan et al. [17,23] informed 121 wild edible plants commonly consume in central Anatolia, 46 wild edible plant taxa belonging to 24 botanical families in Izmir where widely apply Mediterranean diet and those people consume large amount of wild edible plants in this region. Ertug [27] reported 143 wild edible plant are used as a food and beverage in South-western and the most of the plants used as a medicinals and all plant are edible category for animals. The consumption of non-cultivated plants are still important activities despite the socio-economic changes but there is still limited information of their natural production and its agronomic potential [13].

Nowadays, a number of studies have been reported nutrition content of wild edible plants, their role in human nutrition, also high degree of variability reported in nutritional composition of edible plants in widely consumption countries [28, $29,30]$. Nutrient content of some wild edible plants in central black sea region of Turkey were evaluated and eight species shown large variability in terms of N, P, protein and dry matter composition [22]. Furthermore, not only the genetic differentiation among the species was reported also chemical and mineral composition of Prangos ferulacea (L.) and Rheum ribes depending on locations [10]. In addition, Coruh et al. [31] evaluate N, P K, Ca, Mg Na, Fe, $\mathrm{Cu}, \mathrm{Zn}$ and $\mathrm{Mn}$ composition of widespread wild edible species (Sinapis arvensis, Polygonum aviculare, Tragopogon aviculare) and conclude that of examined minerals values depended on species or varieties and growing condition (soil and geographical condition). Significant variation was asses among 21 wild edible plant species, collected form Eastern Anatolia region of Turkey, and examined species showed valuable content of total antioxidant, vitamin $\mathrm{C}$, and phenolic compound [32].

Multivariate statistical analysis is techniques have often been employed to facilitate understanding general distribution of the data leading to a reduction of the initial dimension of data sets and facilitating its interpretation and visualize genotypic differentiation among the species $[33,34,35]$. The principal component analysis has been applied to identify food analyses [36, 37, 38] elemental concentration and compositional profiling of the chili pepper [39], analytical strategy for the geographical identification of plant species [40] such as tomatoes [41], clementine [42], paprika [43], Tropea red onion [44].

The main objective of the present research was undertaken to evaluate nutritional composition widely consuming 17 wild edible leafy plants from Aegean region of Turkey, assess their mineral diversity, and relationships among minerals using multivariate analysis.

\section{Material and methods}

\subsection{Experimental Set Up}

The plant material native found as a weeds and widely distributed in the campus area of Ege University, Turkey, where the plants spontaneously grow and appear as natural populations. The collection site is Department Horticulture, Bornova, Izmir, Turkey, where collecting site is located at $38^{0} 28^{\prime} \mathrm{N}$ latitude, $2^{\circ}{ }^{0} 5^{\prime} \mathrm{E}$ longitude and at an altitude of $25 \mathrm{~m}$ above sea level. In order to reduce environmental and edaphic factors on the composition of the plant samples and to visualize genotypic differentiation among the species, the plant material collected from the a total $500 \mathrm{~m}^{2}$ area where the soil is never cultivated, not use any chemicals such as fertilizer and pesticide in collection site. The nutritional composition analyses were carried out Soil Science and Plant Nutrition Department, Ege University. 


\subsection{Plant Material}

In the present study a total 17 widely consume wild edible species in Aegean region of Turkey, were evaluate for edible parts of nutritional composition (Table 1). In the experiment Lactuca serriola L., Capsella bursa-pastoris L. Medik., Malva sylvestris L., Papaver rhoeas L., Urtica diocia L., Erodium cicutarium (L.) L' Herit., Chondrilla juncea L., Stellaria media L. Rumex patientia L., Taraxanum officinale, Allium scorodoprasum L. subsp. rotundum, Plantago lagopus L., Sonchus asper L. Hill. subsp. glaucescens (Jord.) Ball., Daucus carota L. subsp. carota (L.) Thel., Sinapis arvensis L., Mentha pulegium L., Portulaca oleraceae L. were collected at the same time in early spring when appear and suitable growing stage for consumption. Botanical identification of the species was achieved according to the Davis [45].

\subsection{Chemical Analysis}

A total thirty plant samples were collected by manually for each species and pooled to form a single sample. The edible parts of the plants were gently washed using distilled water and dried at room temperature in order to remove external moisture. They were placed in paper bags and oven-dried at $65^{\circ} \mathrm{C}$ for $24 \mathrm{~h}$. The dried plant samples were ground in a blender for composition determination and nutritional composition of each species analyzed in triplicate.

The total amount of $\mathrm{N}$ in the leaf samples was determined by the modified Kjeldahl method [46]; and protein calculated using with $\mathrm{N}$ values, $\mathrm{P}$ with colorimetry in wet digested samples [47], K, Ca, with flame photometry (Eppendorf, Hamburg, Germany) and Mg, using atomic absorption spectrometry (SpectrAA220 FS; Varian, Mulgrave, VIC, Australia) [48]. Appropriate calibration controls (calibration curve method with commercial certified ICP (Inductively coupled plasma), multi element standard solution; Merck, Darmstadt, Germany) were applied to each set of measurements. N, $\mathrm{P}, \mathrm{K}, \mathrm{Ca}, \mathrm{Mg}$, concentrations were calculated on a dry-weight basis.

\subsection{Data Collection and Statistical Analysis}

Principal component analysis (PCA) was carried out for quantitative data and the total amount of variation was calculated as the sum of extracted eigen values. PCA reduces data and presents different manners for interpretation. PCA techniques can be used to reduce the information of a multidimensional data set in what can be displayed in a scatter plot with only two or three axes. The major part of variance of the data set comes to lie on the first, second and third axes [49]. In addition, the varimax factor rotations were applied in factor analyses in order to make the interpretation of the factors to be considered relevant and in order to maximize the loading of the variables in factors [50], using mathematics. Hierarchical cluster analysis used to classify examined content of samples into groups considering the values of a set of variables. Estimates of Euclidean dissimilarity coefficients were used to assess the relationships between samples according to the similarities examines distance between samples and data set, and it is the most applied cluster analysis method for environmental analysis [33] which was performed using unweighted pairgroup average method [51]. Principal coordinate analyses (PCoA) were performed based on distance matrix, and three dimensional scatter plot was the prepared with the first three principal coordinated to visualize the relationship explained the examined nutritional content. The mean, maximum, minimum values and standard deviation of 8 traits were calculated. All data were processed using Statistica 7 software [52].

\section{Results and discussion}

\subsection{Concentration of Analyzed Traits}

The whole edible part of species was analyzed, dry matters, protein and mineral elements were found to vary depending on species as expected. According to the results, dry matter content of the wild edible species ranged between from $8.65 \%$ to $20.11 \%$ and the highest dry matter obtained from $U$. diocia L. species. These results are in agreement with those reported by other authors indicated dry matter composition ranged (7-29\%) for different wild edible plants [28, 53], and Kibar and Temel [54] underlined that dry matter content varied from $13.90-20.27 \%$ and depending on species. Genetic structure of the species is main factor affecting dry matter content of the plant; in addition, ecological condition, edaphic factors, harvesting stage, and edible parts of plant influenced, additionally genotypic differentiation was reported for nutrient composition of several wild edible species collected from Turkey [14, 55, 22]. 
World Journal of Advanced Research and Reviews, 2021, 12(02), 603-615

Table 1 Botanical name, family, common name and used parts of the examined wild edible species

\begin{tabular}{|l|c|c|l|}
\hline \multicolumn{1}{|c|}{ Botanical name } & Family & Common name & \multicolumn{1}{|c|}{ Part(s) used } \\
\hline Lactuca serriola L. & Asteraceae & Prickly lettuce, milk thistle & Fresh leaves and fresh shoots \\
\hline Capsella bursa-pastoris (L.) Medik. & Brassicaceae & Shepherd's purse, caseweed & Fresh leaves and fresh shoots \\
\hline Malva sylvestris L. & Malvaceae & Common mallow, tall mallow & Fresh leaves and shoots stem \\
\hline Papaver rhoeas L. & Papaveracee & Wild popy, field popy, common popy & Leaves, shoots, petals and seeds sprout \\
\hline Urtica diocia L. & Uticaceae & Stinging nettle, common nettle & Fresh tips and leaves \\
\hline Erodium cicutarium (L.) L'Herit. & Geraniaceae & Common stork's bill, redstem filaree & Fresh leaves and shoots \\
\hline Chondrilla juncea L. & Asteraceae & Skeleton weed, rush skeletonweed & Fresh leaves, shoots, roots \\
\hline Stellaria media L. & Caryophyllaceae & Chickweed, chickenwort, craches & Young leaves stem \\
\hline Rumex patientia L. & Polygoaceae & Patience dock, garden patience & Fresh leaves \\
\hline Taraxanum officinale Web. & Asteraceae & Common dandelion, blowball & Fresh leaves \\
\hline Allium scorodoprasum L. subsp. rotundum Stearn & Liliaceae & Wild leek, wild garlic & Fresh leaves and shoots \\
\hline Plantago lagopus L. & Plantaginaceae & Hare's foot plantain & Fresh leaves \\
\hline Sonchus asper L. Hill. subsp. glaucescens (Jord.) Ball. & Asteraceae & Prickly sow thistle & Fresh leaves and fresh shoots \\
\hline Daucus carota L. subsp. carota (L.) Thel. & Apiaceae & Wild carrot, bird's nest & Young leaves \\
\hline Sinapis arvensis L. & Brassicaceae & Wild mustard, charlock mustard & $\begin{array}{l}\text { Fresh stem and leaves, older leaves, flowers, } \\
\text { fruits, seeds sprout }\end{array}$ \\
\hline Mentha pulegium L. & Lamiaceae & Pennyroyal, squaw mint & Leaves and stem \\
\hline Portulaca oleraceae L. & Portulacaceae & Wild purslane, pursley, verdolaga & Stem and leaves \\
\hline
\end{tabular}


The nitrogen concentration among the examined collection ranged between 2.02-4.79 mg $100 \mathrm{~g}^{-1}$ and the highest $\mathrm{N}$ content observed in C. bursa-pastoris L. Medik. and the lowest $\mathrm{N}$ was found in P. lagopus L., similar trend was shown in protein composition which is calculated using with $\mathrm{N}$ concentration (Figure 1 ), and approximately equivalent to protein content, with some minor exceptions the level of protein in several examined species comparable with high amount protein containing pulses. The values obtained from examined species higher than the values reported for some other wild edible species. Ozbucak et al. [56] pointed out nitrogen content ranged between 1.1-4.2\% in different edible wild plants and underlined that ecological such as temperature and light intensity and genetic factors play role in nitrogen contents of plants [57].
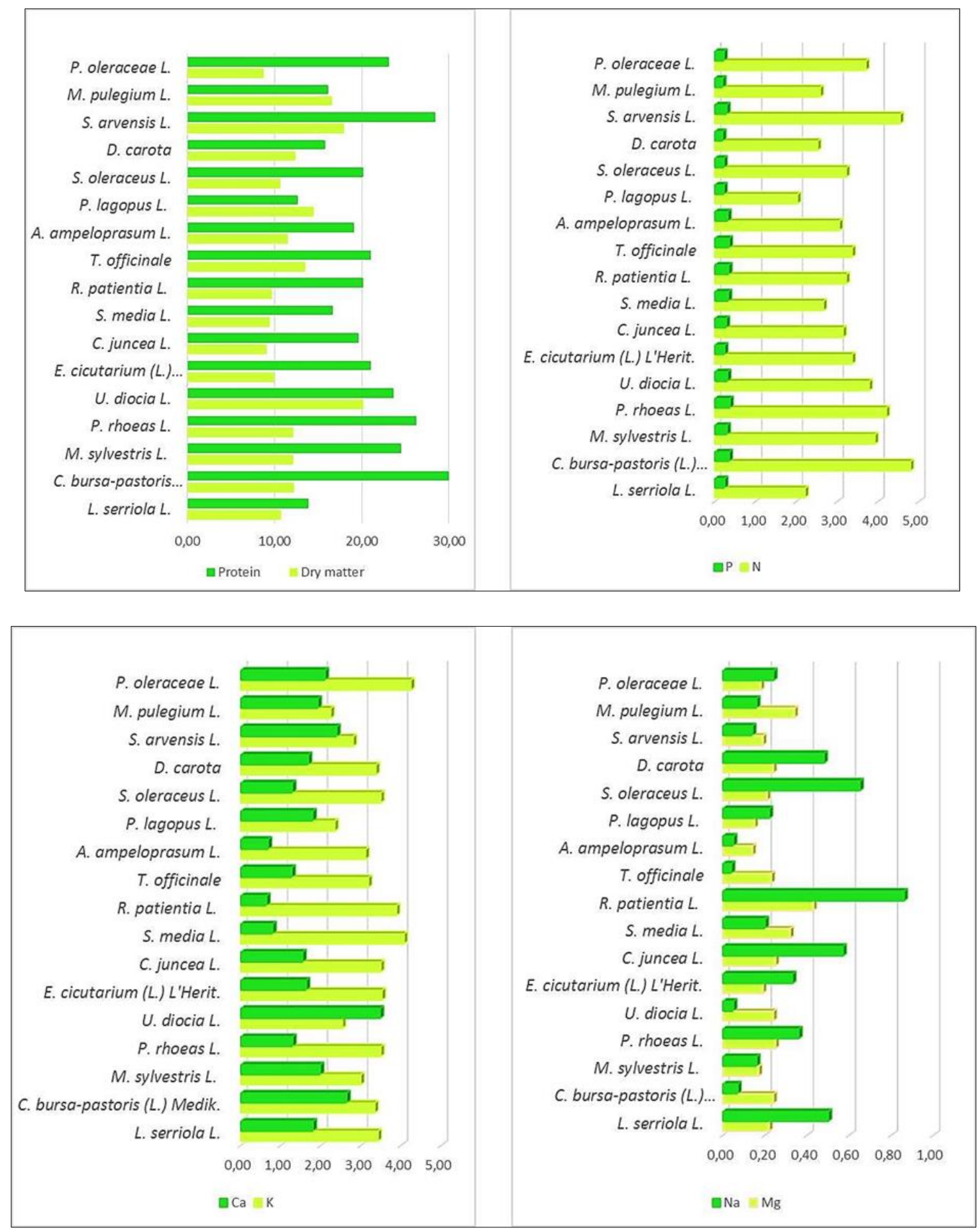

Figure 1 Nutritional composition of 17 wild edible plants 
Turan et al. [5] determined nitrogen content ranged between $0.35-1.70 \%$ and the highest $\mathrm{N}$ values recorded in Polygonaceae family, and Yildirim et al. [14] assessed the range of nitrogen values (0.2-0.7\%) and underlined the highest values received from U. diocia (L.). Kibar and Temel [54] investigated the mineral contents of Bellevalia forniculata, Beta corolliflora, Caltha polypetala and Primula auriculata species and reported that (0.08-0.69\%), these four plant observed higher than commonly cultivated vegetables as lettuce, cabbage, spinach, pepper, broccoli and cauliflower.

In the present research phosphorous content ranged between 0.19-0.37 mg $100 \mathrm{~g}^{-1}$, where $P$. rhoeas showed the highest $\mathrm{P}$ composition and Turan et al. [5] pointed out low variability among various wild edible plant species in terms for $\mathrm{P}$ composition, and ranged from 2.07 to $60.74 \mathrm{mg} 100 \mathrm{~g}^{-1}$. Several researches underlined that growth condition, species, geographical variation and analytical procedures resulted differences between the edible parts of the plant, but Renna et al. [58] highlighted the low influence of the harvesting sites on elements concentration in the wild edible plants and underlined significant differences among the examined species in terms for elements content.

The potassium content was considerably variable on the species and the highest $\mathrm{K}$ content was determined in $M$. pulegium L. $4.24 \mathrm{mg} 100 \mathrm{~g}^{-1}$, whereas the lowest content $2.24 \mathrm{mg} 100 \mathrm{~g}^{-1}$ obtained from P. oleraceae. The potassium content in the present work, in most cases, were different than reported elsewhere. Kibar and Temel [54] underlined that wide range of $\mathrm{K}$ composition (272-5579.1 mg $100 \mathrm{~g}^{-1}$ ) was assess in many wild edible species collected from Turkey $[5,59,31,60,61]$ and foreign countries $[62,63]$.

The Ca content varied from 0.64 to $3.47 \mathrm{mg} 100 \mathrm{~g}^{-1}$ being lowest $R$. patientia L. and highest in U. diocia L. Turan et al. [5] evaluate several Eastern Anatolian wild edible species collected from different site and result revealed that Ca values (27-830 mg $\left.100 \mathrm{~g}^{-1}\right)$ depends on species and growing condition. Ozcan et al. [10] reported Ca composition of two edible plants ( $R$. ribes and $P$. ferulace) ranged between $3.37-42.48 \mathrm{mg} 100 \mathrm{~g}^{-1}$ and argue that genetic differentiation among the species, and location influenced nutritional composition. Several studies reported wide range of Ca composition of wild edible plants and argue that genetically differences among the species accompanied by the environmental and edaphic factor affected mineral composition of plant tissue [5, 59, 31, 60, 54, 61]. Mg values of examined plant collection a very

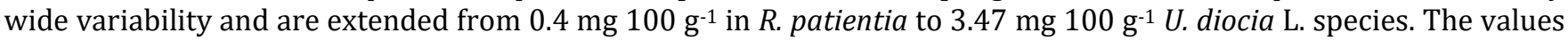
reported by Turan et al. [5] assessed wide range of variability (30.33-293.08 mg $100 \mathrm{~g}^{-1}$ ) among wild edible plants and these results are higher than the present work, but concordance with Kibar and Temel [54] reported that various wild edible plant varied from 30.33-864.3 mg $100 \mathrm{gg}^{-1}[5,59,31,60,63,61]$. The variation in calcium and magnesium could be attributed to one or more factors of genetic, environmental or growth stage of the vegetable during collection [30]. Furthermore, wild edible plant contain higher Mg compared to some cultivated vegetables such as spinach, lettuce, cabbage, celery, broccoli, radish and celery $[64,54]$. Na composition found in the range of $0.04-0.86 \mathrm{mg} 100 \mathrm{~g}-1^{-1}$ respectively, for T. officinale and $R$. patentia L., and mainly low Na values determined in the plant species Turan et al. [5] obtained Na values in the range of 1.09-59.32 mg $100 \mathrm{~g}^{-1}$, Kibar and Temel [54] reported no statistical difference among four wild edible species.

Nowadays many underutilized vegetables usually provide only minor proportion of daily calories, they are observing high level of diversity in terms of nutrition and bioactive components [65]. Different vegetative parts of the wild edible plants can be used a food sources and significant differences reported edible part of the wild plants. Rao [66] stated that oil seed to be a good source of protein and fat. Sankhala et al. [67] evaluate less familiar leafy vegetables including $P$. oleracea in Udaipur region of India and variability reported in proximate composition, iron, calcium, beta-carotene, vitamin $C$ and oxalic acid content. Kalidass and Mohan [68] investigate underutilized food legume and wide range of variability reported for mineral profile, vitamins, fatty acid and amino acid profiles of seed.

\subsection{Correlation Analysis}

In the present research a total seventy wild edible species were evaluate based on nutrition composition in edible parts and there were highly significant differences in all the investigated nutrition among species. The data contained in the present report provide an evidence of the potential examined nutritional values of the indigenous species. Simple correlations analysis of all examined trait shows the moderate to strong coefficients, and coefficients values range from 0 to 1 indicating weak to strong correlations between variables (Table 2). The data presented here show that dry matter positively correlated $\mathrm{Ca}$, while negatively correlated $\mathrm{K}$ and $\mathrm{Na}$. Protein is positively correlated with $\mathrm{N}, \mathrm{P}, \mathrm{Ca}$ content: $\mathrm{N}$ is positively correlated $\mathrm{P}$ and Ca. Potassium negatively correlated $\mathrm{Ca}$, whereas positively N. Phosphorus positively correlated with protein and $\mathrm{N}$ content; also, $\mathrm{Na}$ is positively correlated with $\mathrm{Mg}$ while negatively correlated with $\mathrm{Na}$ composition. 
Table 2 Pearson correlations coefficient of the nutritional status of examined wild edible species

\begin{tabular}{|c|c|c|c|c|c|c|c|}
\hline & Dry matter & Protein & $\mathbf{N}$ & $\mathbf{P}$ & $\mathbf{K}$ & $\mathrm{Ca}$ & Mg \\
\hline Protein & 0.192 & & & & & & \\
\hline $\mathrm{N}$ & 0.192 & $1.00^{* *}$ & & & & & \\
\hline $\mathrm{P}$ & -0.007 & $0.555^{*}$ & $0.555^{* *}$ & & & & \\
\hline $\mathrm{K}$ & $-0.780^{* *}$ & 0.104 & 0.104 & 0.200 & & & \\
\hline $\mathrm{Ca}$ & $0.647^{* *}$ & $0.405^{*}$ & $0.405^{*}$ & -0.157 & $-0.447^{*}$ & & \\
\hline $\mathrm{Mg}$ & -0.117 & -0.112 & -0.112 & 0.201 & 0.191 & -0.270 & \\
\hline $\mathrm{Na}$ & $-0.541^{*}$ & -0.294 & -0.294 & -0.205 & $0.421^{*}$ & $-0.438^{*}$ & $0.474^{*}$ \\
\hline
\end{tabular}

\subsection{Principal Component Analysis}

In order to evaluate mineral accumulation among species in a diversity context principal component analysis were applied by all eight variables. Multivariate analysis revealed considerable variation for the most of concentration. The principal component (PC) analysis explained $81.49 \%$ of total variation accounted for three PC axis (Table 3). The higher loading of the variable implies larger contribution of to the variation. The rotated loadings and communality for each variable were given in the table 3. The first PC axis accounting for $32.34 \%$ of the variations and mainly comprises protein, $\mathrm{N}$ and $\mathrm{P}$ compositions. The second $\mathrm{PC}$ explained $31.74 \%$ of total variations, concerned with dry matter, $\mathrm{K}, \mathrm{Ca}$, and $\mathrm{Na}$. The third PC axis accounted for $17.41 \%$ of the total variations and concerned with $\mathrm{Mg}$.

Table 3 Minimum ( $\mathrm{min}$ ), mean, maximum (max), standard deviation (SD), Eigen values proportion of variability, and minerals contributed to the principal components of wild edible species.

\begin{tabular}{|l|c|c|c|c|c|c|c|c|}
\hline & & & & & \multicolumn{4}{|c|}{ PC axis } \\
\hline Eigenvalues & & & & & 2.59 & 2.54 & 1.39 \\
\hline Explained proportion of variation & & & & & 32.34 & 31.74 & 17.41 \\
\hline Cumulative proportion of variation & & & & & 32.34 & 64.09 & 81.50 \\
\hline & & & & & \multicolumn{4}{|c|}{ Eigen values } \\
\hline Properties & Min & Mean & Max & SD & $\mathbf{1}$ & $\mathbf{2}$ & $\mathbf{3}$ \\
\hline Protein & 12.63 & 29.94 & 20.7 & 4.76 & 0.947 & 0.118 & -0.166 \\
\hline $\mathrm{N}$ & 2.02 & 4.79 & 3.32 & 0.76 & 0.947 & 0.118 & -0.166 \\
\hline $\mathrm{P}$ & 0.19 & 0.37 & 0.28 & 0.06 & 0.773 & -0.097 & 0.261 \\
\hline Dry matter & 8.65 & 20.11 & 12.54 & 3.21 & 0.091 & 0.953 & -0.006 \\
\hline $\mathrm{K}$ & 2.24 & 4.24 & 3.28 & 0.55 & 0.239 & -0.883 & 0.037 \\
\hline $\mathrm{Ca}$ & 0.64 & 3.47 & 1.70 & 0.70 & 0.239 & 0.709 & -0.313 \\
\hline $\mathrm{Na}$ & 0.04 & 0.86 & 0.29 & 0.23 & -0.267 & -0.551 & 0.509 \\
\hline $\mathrm{Mg}$ & 0.14 & 0.43 & 0.23 & 0.07 & 0.047 & -0.088 & 0.955 \\
\hline
\end{tabular}

\subsection{Cluster and Principal Coordinate Analysis}

The hierarchical agglomerative clustering performed for nutritional composition and the classified into the clusters (Figure 2). Nutritional composition of the examined species is reflected by cluster analysis and divided into the three main clusters. 
Cluster analysis allowed these data to be integrated to evaluate which qualitative variables (considered simultaneously) contributed the most to the differences among the groups (i.e., species). Disciglio et al. [69] evaluate the protein, mineral levels (such as nitrates $\mathrm{P}, \mathrm{K}, \mathrm{Ca}, \mathrm{Mg}, \mathrm{Na}$ ) polyphenol content and the antioxidant activity of the main wild herbaceous food species consumed in Foggia Province, Italy and the cluster analysis of all the qualitative characteristics of the species identified into five clusters.

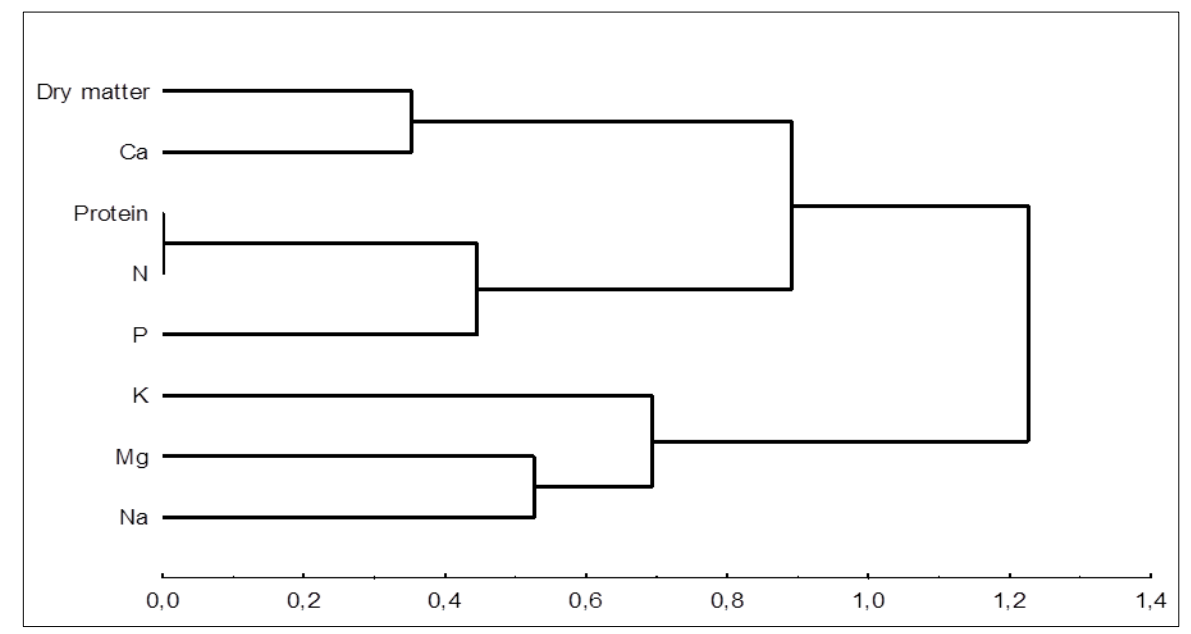

Figure 2 Dendrogram based on dissimilarity matrix constructed from nutritional composition of 17 wild edible plants using unweighted pair-group average method

In order to demonstrate relationships of investigated minerals factor analysis was applied, and the first three principal co-ordinates are given 3D (dimension) scatter plot (Figure 3). Mineral elements separate their corresponding value of explained proportion of variation in the scatter plot. Multivariate analysis was not widely applied to assessment diversity context in the mineral concentration among wild edible plant.

The results of experiments revealed that the first three principal components were highly valid to classify the examined species and separating mineral accumulations. Disciglio et al. [69] underlined that the dry matter content, the chloride, phosphorus, potassium, and fluoride levels and the protein content effectively differentiated between many of these examined 11 wild edible plant groups covering S. arvensis L. and P. oleracea L.

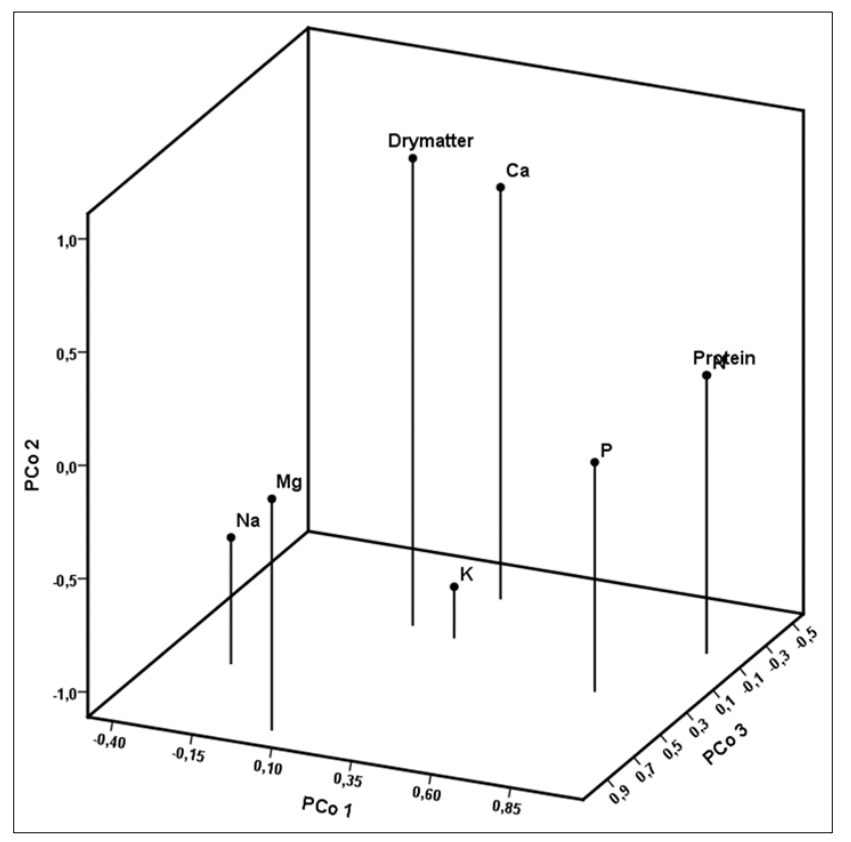

Figure 3 Patterns of relationships among wild edible species due to the first three principal co-ordinates 
Plants or their products have been use as a food source, medicine, production of materials or magic rituals from ancient times and many wild plants became cultivated species in ancient Greece [70]. However, with development of modern agriculture people focused more on domesticated cultivars and gave less attention to wild species. Ethnobotanical studies showed that more than 30,000 plant species can be classified as an edible, and from this amount about 7,000 species have been used for human diet [71]. Nowadays, ethnobotanical studies revealed that the information on the traditional knowledge of wild edible plants is disappearing today; furthermore, in this century most of the human $80 \%$ of total dietary energy intake obtained from twelve domesticated species eight from cereals and four from tubers [72].

A large number of wild edible plants are consuming as foods in various different areas of Mediterranean Basin, and consume in variety of ways, the high percentage of wild edible plant consume as a raw in salad. Nowadays in most countries, selling of green wild vegetables often sold in Mediterranean countries mainly in Italy, Greece, Croatia, Spain and Turkey. In the last decade, there has been a return to natural food, however new generations are not familiar wild edible plant and most of the traditional knowledge of wild food plants is disappearing and in most cases, survives only with the elderly $[73,74]$. Apart from the traditional consumption, some of the important wild edible plants could be collected for commercial purposes; wild food plants re-discovered and re-created by many restaurants tend to use many wild species in their kitchen [75]. In addition to the economic importance of underutilized wild edible plant has been increase and research underlined that they possess high nutritional value compared with the cultivated species. In latest years' researchers, more focus on nutritional composition of the widely consuming fruit and vegetables, and plant breeders take into consideration improving nutritional status of edible part of the cultivated species.

In this context, wild edible plants are present valuable nutrient sources for alternative nutrition for achieving balanced human diet. Unlike the domesticated cultivated species that may require higher input for production wild edible plants can easily find from gardens farmlands or other habitats. Furthermore, most of the wild edible species are adapted marginal agro-climatic conditions, and some of them can be selected and developed as future crops [30]. Focusing on wild edible species is an effective way to reduce micro and macronutrient deficiency and improving food security.

\section{Conclusion}

The present study analytical investigations were carried out to ascertain dry matter, protein, $\mathrm{N}, \mathrm{P}, \mathrm{K}, \mathrm{Ca}, \mathrm{Mg}$ and $\mathrm{Na}$ content of widely consuming wild edible species Aegean region of Turkey. The result show that among the examined species $C$. bursa-pastoris L. Medik., and S. arvensis showed higher values for protein content, $U$. diocia was rich in Ca, $P$. oleraceae L. and $S$. media good sources for $\mathrm{K}, R$. patientia contain high amount of Mg. The current work is underlined that examined wild edible plant species contain large amount of mineral element, also exhibited great variability and the fact that most of the wild plants are perceived as highly useful for future exploitation of health foods. Despite wild edible species observe high nutritional value, health benefit compound and important source for people further research needed for evaluation agronomic potential.

\section{Compliance with ethical standards}

\section{Acknowledgments}

The authors would like to thank the all the co-authors for their invaluable contributions towards the success of this work.

\section{Disclosure of conflict of interest}

The authors declared that there is no conflict of interests regarding the publication of this paper.

\section{References}

[1] Ghirardini MP, Carli M, Del Vecchio N, Rovati A, et al. The importance of a taste. A comparative study on wild food plant consumption in twenty-one local communities in Italy. Journal of ethnobiology and ethnomedicine. 2007; 3: 22 .

[2] Nassif F, Tanji A. Gathered food plants in Morocco: the long forgotten species in ethnobotanical research. Life science leaflet. 2013; 3: 17-54. 
[3] Tardio J. Spring is coming: the gathering and consumption of wild vegetables in Spain. In: Pardo-de-Santayana M, Pieroni A, Puri R, eds. Ethnobotany in the New Europe: people, health and wild plant resources. Oxford, UK, Berghahn Press; 2010. p. 211-38.

[4] Molina M, Pardo-De-Santayana M, Tardio J. Natural production and cultivation of Mediterranean wild edibles. In: Sanches-Mata MC, Tardio J, eds. Mediterranean wild edible plants. Springer; 2016. p. 81-107.

[5] Turan M, Kordali S, Zengin H, Dursun A, Yildirim S. Macro and micro mineral content of some wild edible leaves consumed in Eastern Anatolia. Acta agriculturae scandinavica, section B, soil plant science. 2003; 53(3): 129-137.

[6] Ju Y, Zhuo J, Liu B, Long C. Eating from the wild: diversity of wild edible plants used by Tibetans in Shangri-la region, Yunnan, China. Journal of ethnobiology and ethnomedicine. 2013; 9(1): 28.

[7] Salvi J, Katewa SS. A review: Underutilized wild edible plants as a potential source of alternative nutrition. International journal of botanical studies. 2016; 1(4): 32-36.

[8] Green C. An overview of production and supply trends in the U.S. specialty vegetable market. Acta horticulturae. 1992; 318: 41-45.

[9] Bianco VV, Santamaria P, Elia A. Nutritional value and nitrate content in edible wild species used in southern Italy. Proceeding 3rd international symposium on diversification of vegetable crops, Acta horticulturae. 1998; 467: 71-87.

[10] Ozcan MM, Dursun N, Arslan D. Some nutritional properties of Prangos ferulacea (L.) lidl and Rheum ribes L. stems growing wild in Turkey. International journal of food science and nutrition. 2007; 58(2): 162-67.

[11] Kibar B, Kibar H. Determination of the nutritional and seed properties of some wild edible plants consumed as vegetable in the Middle Black Sea Region of Turkey. South African journal of botany. 2017; 108: 117-25.

[12] Pinela J, Carocho M, Dias MI, Caleja C, Barros L, Ferreira ICFR. Wild plant-based functional foods, drugs, and nutraceuticals. In: Ferreira ICFR, Morales P, Barros L, eds. Plants, mushrooms and nut. Chichester, UK: John Wiley\&Sons, Ltd; 2016. p. 315-51.

[13] Molina M, Tardio J, Aceituno-Mata L, Morales R, Reyes-Karcia V, Pardo-De-Santayana M. Weeds and food diversity: natural yield assessment and future alternatives for traditionally consumed wild vegetables. Journal of ethnobiology. 2014; 34(1): 44-67.

[14] Yildirim E, Dursun A, Turan M. Determination of the nutrition contents of the wild plants used as vegetables in upper Coruh Valley. Turkish journal of botany. 2001; 25: 367-71.

[15] Agarwal JK, Saini P. Nutritional assessment of leaves of wild edible plant Urtica ardence. Indian journal of pharmacy and biological research. 2013; 1(2): 53-59.

[16] Tuncturk M, Celen AE, Tucturk R. Nutrient content of three edible wild plants from Polygonaceae Family. Oxidative communication. 2017; 40(1-2): 327-34.

[17] Dogan Y, Baslar S, Ay G, Mert HH. The use of wild edible plants in Western and Central Anatolia (Turkey). Economy botany. 2004; 58(4): 684-90.

[18] Tardio J, Pardo-De-Santayana M, Morales R. Ethnobotanical review of the wild edible plants in Spain. Botanical journal of linnean society. 2006; 152: 27-71.

[19] Hussain J, Rehman NR, Khan AL, Hamayun M, Hussain SM, Shinwari ZK. Proximate and nutrients evaluation of selected vegetables species from Kohat region Pakistan. Pakistan journal of botany. 2010; 42(4): $2747-55$.

[20] Hazrat A, Nisar M, Shah J, Ahmad S. Ethnobotanical study of some elite plants belonging to Dir, Kohistan Valley, Khyber Pukhtunkhwa Pakistan. Pakistan journal of botany. 2011; 43(2): 787-95.

[21] Wetherilt H, Pala M. Plants and spices indigenous to Turkey. Spices, plants and fungi and development. Food science. 1994; 34: 285-307.

[22] Ozbucak TB, Akcin OE, Yalcin S. Nutrition contents of the some wild edible plants in Central Black Sea Region of Turkey. International journal of natural engineering science. 2007; 1: 11-13.

[23] Dogan Y, Ugulu I, Durkan N. Wild edible plants sold in the local markets of Izmir Turkey. Pakistan journal of botany. 2013; 45(s1): 177-84. 
[24] Esiyok D, Bozokalfa MK, Kaygisiz Asciogul T. Widely utilized wild edible plant a-case study from Turkey. In: Global perspectives on underutilized crops, Ozturk M, Hakeem KR, Asraf M, Sajid Ayeel Ahmad M, eds. Springer; 2018. p. 217-57.

[25] Abak K, Duzenli A. Use of some wild plants as vegetables in Turkey. Acta horticulturae. 1989; 242: 107-14.

[26] Tan A, Adanacioglu N, Karabak S, Aykas L, Tas N, Taylan T. Biodiversity for food and nutrition: Edible wild plant species of Aegean Region of Turkey. Anadolu. 2017; 27(2): 1-8.

[27] Tan Ertug F. Wild edible plants of the Bodrum Area (Mugla, Turkey). Turkish journal of botany. 2004; 28: 16174.

[28] Guil UR, Rodrigez-Garcia I, Torija E. Nutritional and toxic factors in selected wild edible plants. Plant foods for human nutrition. 1997; 51: 99-107.

[29] Gupta S, Lakshmi AJ, Manjunath M, Prakash J. Analysis of nutrient and anti-nutrient content of underutilized green leafy vegetables. LWT-Food science and technology. 2005; 38: 339-45.

[30] Addis G, Asfaw Z, Singh V, Woldu Z, Baidu-Forson JJ, Bhattachara S. Dietary values of wild and semi-wild edible plants in southern Ethiopia. African journal of food, agriculture, nutrition and development. 2013; 13(2): 748503.

[31] Coruh I, Gormez AA, Ercisli S, Bilen S. Total phenolics, mineral elements, antioxidant and antibacterial activities of some edible wild plants in Turkey. Asian journal of chemistry. 2007; 19: 5755-62.

[32] Samancioglu A, Sat IG, Yildirim E, Ercisli S, Jurikova T, Mlcek J. Total phenolic and vitamin C content and antiradical activity evaluation of traditionally consumed wild edible vegetables from Turkey. Indian journal of traditional knowledge. 2016; 15(2): 208-13.

[33] Tokalioglu S. Determination of trace elements in commonly consumed medicinal herbs by ICP-MS and multivariate analysis. Food chemistry. 2012; 134: 2504-08.

[34] Bozokalfa MK, Esiyok D, Yagmur B. Use of multivariate analysis in mineral accumulation of rocket (Eruca sativa) accessions. Genetika. 2011; 43(3): 437-48.

[35] Bozokalfa MK, Kaygisiz Asciogul T, Esiyok D. Genetic diversity of farmer-preferred cowpea (Vigna unguiculata L. Walp) landraces in Turkey and evaluation of their relationships based on agromorphological traits. Genetika. 2017; 49(3): 935-57.

[36] Gong S, Luo L, Gong W, Gao Y, Xie M. Multivariate analyses of element concentrations revealed the groupings of propolis from different regions in China. Food chemistry. 2012; 134: 583-88.

[37] Karadas C, Kara D. Chemometric approach to evaluate trace metal concentrations in some spices and herbs. Food chemistry. 2012; 130: 96-202.

[38] Sarbu C, Nascu-Briciu RD, Kot-Wasik A, Gorinstein S, Wasik A, Namiesnik J. Classification and fingerprinting of kiwi and pomelo fruits by multivariate analysis of chromatographic and spectroscopic data. Food chemistry. 2012; 130: 994-02.

[39] Naccarato A, Furia E, Sindona G, Tagarelli A. Multivariate class modeling techniques applied to multielement analysis for the verification of the geographical origin of chili pepper. Food chemistry. 2016; 206: $217-22$.

[40] Luykx DMAM, Van Ruth SM. An overview of analytical methods for determining the geographical origin of food products. Food chemistry. 2008; 107: 897-11.

[41] Lo Feudo G, Macchione B, Naccarato A, Sindona G, Tagarelli A. The volatile fraction profiling of fresh tomatoes and triple concentrate tomato pastes as parameter for the determination of geographical origin. Food research international. 2011; 44: 781-88.

[42] Benabdelkamel H, Di Donna L, Mazzotti F, Naccarato A, Sindona G, Tagarelli A, Taverna D. Authenticity of PGI "Clementine of Calabria" by multielement fingerprint. Journal of agriculture and food chemistry. 2012; 60: 371726.

[43] Palacios-Morillo A, Jurado JM, Alcazar A, De Pablos F. Geographical characterization of Spanish PDO paprika by multivariate analysis of multielemental content. Talanta. 2014; 128: 15-22. 
[44] Furia E, Naccarato A, Sindona G, Stabile G, Tagarelli A. Multielement fingerprinting as a tool in origin authentication of PGI food products: Tropea red onion. Journal of agriculture and food chemistry. 2011; 59: 845057.

[45] Davis PH. Flora of Turkey and East Aegean Islands. University Press, Edinburg. 1982.

[46] Bremner JM. Total nitrogen. In: Black CA, ed. Methods of soil analysis. Part 2: Chemical and microbial properties. Number 9 in series agronomy. American society of agronomy inc. Publisher, Madison, Wisconsin, USA; 1965. p. 1049-178.

[47] Loot WL, Nerry JP, Gallo JR, Medcaff JC. Leaf analysis technique in coffee research. IBEC Research Institute. II. 9., New York; 1956. p. 21-24.

[48] Kacar B, Inal A. Bitki analizleri. Nobel Yayın Dagıtım, Ankara, Turkey. 2008.

[49] Friedt W, Snowdon R, Ordon F, Ahlemeyer J. Plant breeding assessment of genetic diversity in crop plants and its exploitation in breeding. Progress in botany. 2007; 168: 152-78.

[50] Fadigas JC, Dos Santos AM, De Jesus RM, Lima DC, Fragoso WD, David JM, Ferreira SLC. Use of multivariate analysis techniques for the characterization of analytical results for the determination of the mineral composition of kale. Microchemical journal. 2010; 96: 352-56.

[51] Rabbani MA, Iwabuchi A, Murakami Y, Suzuki T, Takayanagi K. Genetic mustard (Brassica juncea L.) germplasm from Pakistan as determined by RAPDs. Euphytica. 1998; 103: 235-42.

[52] Statsoft, Statistica package release 7. StatSoft, Inc., Tulsa, USA. 2004.

[53] Escudero NL, De Arellano ML. Taraxacum officinale as a food source. Plant foods for human nutrition. 2003; 58: $1-10$.

[54] Kibar B, Temel S. Mineral content of some wild edible plants growing in Eastern Anatolia Region grassland of Turkey and consumed as vegetable. Journal of food processing and preservation. 2016; 40: 56-66.

[55] Sekeroglu N, Ozkutlu F, Deveci M, Dede O, Yilmaz N. Evaluation of some wild plants in terms of their nutritional values used as vegetable in Eastern Black Sea Region of Turkey. Asian journal of plant science. 2006; 5: $185-89$.

[56] Lakshmi B, Vimala V. Nutritive value of dehydrated green leafy vegetable powders. Journal of food Science Technology. 2000; 37: 465-71.

[57] Gurses OL. Nitrate amount of tea and examine of health. Food. 1983; 8: 275-78.

[58] Renna M, Cocozza C, Gonnella M, Abdelrahman H, Santamaria P. Elemental characterization of wild edible plants from countryside and urban areas. Food chemistry. 2015; 177: 29-36.

[59] Demir H. Chemical composition of some wild (Polygonum cognatum, Tragopoxgom reticulatus and Berberis vulgaris) plants collected from Erzurum. Bahce. 2006; 35: 55-60.

[60] Akgunlu SB. Mineral content and microbiological analysis of some wild edible vegetables consumed in Kilis and Gaziantep provinces. MSc Thesis, 59 p., Kilis 7 Aralik University, Graduate School of Natural and Applied Sciences, Department of Biology, Turkey. 2012.

[61] Tuncturk M, Ozgokce F. Chemical composition of some Apiaceae plants commonly used in herby cheese in Eastern Anatolia. Turkish journal of agriculture and forestry. 2015; 39: 55-62.

[62] Sena LP, Vanderjagt DJ, Rivera C, Tsin ATC, Muhamadu I, Mahamadou O, Millson M, Pastuszyn A, Glew RH. Analysis of nutritional components of eight famine foods of the Republic of Niger. Plants foods for human nutrition. 1998; 52: 17-30.

[63] Seal T, Chaudhuri K. Ethnobotanical importance and nutritional potential of wild leafy vegetables of Meghalaya state in India. International journal of applied biology and pharmacy. 2015; 6: 80-85.

[64] Holland L, Unwind D, Bus DH. Fruits and Nuts. First supplement to 5th edition of McCance and Widdowson's. The composition of foods. Royal society of chemistry, Cambridge. 1992.

[65] Kang Y, Luczaj L, Kang J, Wang F, Hou J, Guo Q. Wild food plants used by the Tibetans of Gongba Valley (Zhouqu county, Gansu, China). Journal of ethnobiology and ethnomedicine. 2014; 10: 20.

[66] Rao PU. Nutrient composition of some less familiar oil seeds. Food chemistry. 1994; 50: 379-82. 
[67] Sankhala A, Sankhla AK, Bhatnagar B, Singh A. Nutrient composition of less familiar leaves consumed by the tribal's of Udaipur region. Journal of food science and technology. 2005; 42(5): 446-48.

[68] Kalidass C, Mohan VR. Biochemical composition and nutritional assessment of selected under-utilized food legume of the genus Rhynchosia. International food research journal. 2012; 19(3): 977-84.

[69] Disciglio G, Tarantino A, Frabboni L, Gagliardi A, Giuliani MM, Tarantino E, Gatta G. Qualitative characterization of cultivated and wild edible plants: mineral elements, phenols content and antioxidant capacity. Italian Journal of agronomy. 2017; 12: 383-394.

[70] Torija-Isasa ME, Matallana Honzalez MC. A historical perspective of wild plants foods in the Mediterranean area. In: Sanches Mata MC, Tardio J. eds. Mediterranean wild edible plants. Springer; 2016. p. 3-13.

[71] Wilson KB. Ecological dynamics and human welfare: A case study of population, health and nutrition in southern Zimbabwe. [PhD Thesis]. Department of Anthropology. University College, UK. 1990.

[72] Grivetti LE, Ogle BM. Value of traditional foods in meeting macro and micronutrient needs: the wild plant connection. Nutrition research review. 2000; 3: 31-46.

[73] Luczaj L, Kohler P, Piroznikow E, Graniszewska M, Pieroni A, Gervasi T. Wild edible mixes sold in the markets of Dalmatia (Southern Croatia). Journal of ethnobiology and ethnomedicine. 2013; 9: 2.

[74] Tardio J, Pardo-De-Santayana M. Ethnobotanical analysis of wild fruits and vegetables traditionally consumed in Spain. In: Sanches Mata MC, Tardio J. eds. Mediterranean wild edible plants. Springer; 2016. p. 57-80.

[75] Luczaj K, Pieroni A. Nutritional ethnobotany in Europe: from emergency food to healthy folk cuisines and contemporary foraging trends. In: Sanches Mata MC, Tardio J, eds. Mediterranean wild edible plants. Springer; 2016. p. 33-56. 